\title{
Recent data on nitrogen utilization and requirements in dairy goats
}

\author{
J. BRUN-BELLUT *, S. GIGER **, D. SAUVANT **, G. BLANCHART * \\ *E.N.S.A.I.A., Zootechnie, 2, av. de la Forêt-de-Haye, 54500 Vandouvre (France) \\ ** I.N.R.A., Station de Nutrition et Alimentation \\ I.N.A. P.G., 16, rue Claude-Bernard, 75231 Paris Cedex 05 (France)
}

To improve the knowledge of nitrogen utilization in dairy goats to specify their nitrogen requirements, we used a model which expressed digested nitrogen (Dig. $\mathrm{N}$ ) or limiting PDl (Lim. PDI : the lowest value between PDIN and PDIE) on the basis of various parameters correlated with maintenance, milk production and nitrogen losses in urine (excess of fermentescible nitrogen in the rumen or digestible amino acids in animals). These losses were estimated using plasma urea level (PUL) or milk urea level (MUL).

\section{Results}

Two series of results were obtained :

1) With high level of nitrogen intake (Paris): The diets were mainly made of lucerne hay and maize silage. They were fed to lactating or dry pregnant goats.

Lim. PDI $=1.04+8.48$ milk $\mathrm{N}+3.08 \mathrm{~N}$ balance $+6.26 \mathrm{PUL}$.

$r=0.84$; or $=1.64$.

Dig. $\mathrm{N}=0.11+1.36$ milk $\mathrm{N}+0.82 \mathrm{~N}$ balance +1.48 PUL.

$r=0.84$; or $=0.30$.

2) With medium or low level of nitrogen intake (Nancy): The diets were mainly made of dried beet pulps or dried grass. Only positive nitrogen balances were kept :

Lim. PDI $=1.51 \mathrm{~W}^{0.75}+3.7 \mathrm{~N}$ balance +8.5 milk protein $\mathrm{N}+0.6 \Delta \mathrm{PDI}+168 \mathrm{MUL}$.

$\mathrm{r}=0.89 ;$ or $=21.5$.

Dig. $\mathrm{N}=0.32 \mathrm{~W}^{0.75}+0.8 \mathrm{~N}$ balance +1.28 milk protein $\mathrm{N}+18.6 \mathrm{MUL}$.

$r=0.997 ;$ or $=4.07$.

The results obtained in Nancy showed that maintenance requirements were $0.32 \mathrm{~g}$ Dig. N/kg W 0.75 or $1.51 \mathrm{~g}$ PDI $/ \mathrm{kg} \mathrm{W.075}$. The efficiency of milk protein nitrogen production was 0.78 on the basis of the digested nitrogen and 0.74 on the basis of PDI intake.

The results obtained in Paris did not allow to estimate maintenance requirements because the model did not take the weight into account. They showed that the efficiency of milk nitrogen production was 0.74 on the basis of the digested nitrogen or PDI intake.

Key words : Nitrogen requirement, dairy goat, balance.

\section{Estimation of nitrogen nutritional status in dairy goats}

\section{J. BRUN-BELLUT, F. LAURENT, G. BLANCHART}

E.N.S.A.I.A., Zootechnie, 2, av. de la Forêt-de-Haye, 54500 Vandauvre (France)

Nitrogen nutritional status of dairy goats at maintenance or during lactation is difficult to determine. We were therefore interested in finding some indicators of this status and reviewed several parameters of nitrogen metabolism which could be measured in blood, milk or urine. 
Beside the information supplied by nitrogen metabolism, blood urea is the most frequently cited in the literature. Thus, plasma urea level (PUL) varies with dietary nitrogen content (BAS et al., 1980 ; GIGER \& SAUVANT, 1985). In latin square experiments with dairy goats, we showed that PUL varied widely with feeding frequency or starvation and with time of sampling. These variations reduce the significance of PUL for the estimation of nutritional status in dairy goats.

Milk urea level (MUL) was strongly correlated with PUL $(r=0.91, n=189)$. MUL could be considered as a good estimator of PUL daily mean. TUL was correlated with : 1) the difference between dietary PDIN and PDIE values ; 2) the excess of digestible nitrogen intake over digestible nitrogen requirements.

Using 169 nitrogen balances in lactating goats, we showed that urinary allantoin (U. All) was strongly correlated with digestible organic matter and fermentescible nitrogen $(r=0.67)$. U. All could be used as an indicator of rumen microbial activity but several physiological factors which might interfere should be taken into account.

Mean blood allantoïn level in dairy goats was $35.7 \mathrm{mg} / 1(\sigma=6.3, \mathrm{n}=58)$. We did not find any correlation between U. All and blood allantoïn level.

Orotic acid content of milk measured for the first five months of lactation $(9.1 \mathrm{mg} / 1$; $\sigma=2.3 \mathrm{mg} / \mathrm{l}, \mathrm{n}=159$ ) varied especially during the first month but did not change after this period. For that reason, milk orotic acid was a poor indicator of nitrogen metabolism.

In conclusion, the simultaneous utilization of milk urea level and urinary allantoïn excretion might improve our knowledge of the nitrogen nutritional status in dairy goats.

Key words : Dairy goats, urea, allantoïn, nitrogen.

\title{
Preliminary studies on nitrogen nutrition of lactating Damascus goats
}

\author{
M. HADJIPANAYIOTOU \\ Agricultural Research Institute, Nicosia, Cyprus
}

Three trials were conducted to study the effect of $\mathrm{N}$-intake on the performance of lactating goats. The concentrate mixtures used in these studies were composed of barley grain, a $\mathrm{N}$-supplement source (soybean meal, urea or fish meal) wheat bran and a macro/micro element vitamin mixture. The mixtures were fed along with barley straw $(0.2 \mathrm{~kg} / \mathrm{head} / \mathrm{day})$ and barley hay $(0.5 \mathrm{~kg} / \mathrm{head} / \mathrm{day})$ to meet maintenance and milk production energy requirements. Dietary $\mathrm{N}$ concentration in the concentrate mixture was adjusted by altering the proportion of the $\mathrm{N}$-supplement. Dietary $\mathrm{N}$-concentration did not affect total feed intake in any of the 3 trials.

In trial 1, 49 goats were randomly assigned to 2 diets (10 or 14 p. $100 \mathrm{CP}$ ) on the 3rd day post kidding. The trial lasted until weaning of kids ( $55 \pm 2$ days). Increasing CP-intake through higher levels of soybean meal, improved milk yield (MY) $(2.95$ v $2.49 \mathrm{~kg} /$ day) and milk CP-content $(40 \mathrm{v} 36 \mathrm{~g} / \mathrm{kg}$ ). Type of suckling (single $\mathrm{v}$ twin) affected MY (single $2.25 \mathrm{v}$ twin $3.21 \mathrm{~kg} /$ day). CP-intake of goats did not affect growth rate of kids.

In trial 2, 12 goats ( 75 days in milk) were allocated to 4 groups. Within each group, goats randomly received one of $4 \mathrm{~N}$-supplements : soybean meal (S), fish meal (F), S plus urea (SU) or FU. For each group, a $3 \times 3$ Latin square with three 22 day periods and 3 levels : 80,120 or $160 \mathrm{~g} \mathrm{CP} / \mathrm{kg}$ DM was used. Increasing CP-intake resulted in higher MY in the FU group only. Differences in MY among N-supplements were not significant ( $\mathrm{S} 1.79$; SU $1.88 ; \mathrm{F} 1.89 ; \mathrm{FU} 1.91 \mathrm{~kg} /$ goat). In all groups, higher $\mathrm{CP}$-intake did not alter milk composition or $\mathrm{OM}$ digestibility but increased $\mathrm{CP}$ digestibility ; urinary-N output, $\mathrm{N}$-absorbed 